\title{
Study on architecture and microclimate effect of combined container roof garden
}

\author{
Dongtao Luan and Zhiguo Zhang \\ ${ }^{1}$ School of Shanghai Institute of Technology, Shanghai 201418, China
}

Keywords: Roof garden; Air temperature; Surface temperature; Indoor temperature; RH

\begin{abstract}
The objective of this study is to investigate the effect of combined container roof garden on the microclimate, the wall temperature and the indoor temperature of the building. This study has shown that the combined container roof garden can effectively improve the roof microclimate, reduce the highest air temperature $1.9{ }^{\circ} \mathrm{C}$, increase the daily average air relative humidity(RH)13.72\%. The study also shows that the combined container roof garden can reduce surface temperature and indoor temperature of buildings, reduce surface temperature $14.2{ }^{\circ} \mathrm{C}$ and reduce indoor temperature $8.9^{\circ} \mathrm{C}$ mostly. The different regions in roof garden has the influence on microclimate, the wall temperature and the indoor temperature, the reason is different regions have diverse green space and plants. It is more obvious to improve the micro climate when green areas are larger. Meanwhile, shrub and small arbors are the most suitable plant for the roof garden.
\end{abstract}

\section{Introduction}

Environmental problems, especially in urban areas, such as Shanghai, have become a serious issue. There has been a tremendous growth in population and buildings in cities, the increasing numbers of buildings in cities causes a loss of green areas, resulting in the Urban Heat Island effect (UHI). In such a situation, the research and development of roof gardens has been increasing, because roof garden can enrich the urban landscape, reduce energy consumption. There is evidence that the installation of rooftop greenery can achieve savings of $1-15 \%$ in annual energy consumption and17-79\% in both space cooling and peak space loads [1-2]. Aside from providing temperature control, hydrological benefits, and energy reduction, the roof gardens can also serve as habitats for wildlife [3-10]. However, the contraction of the traditional roof garden is complex, and the requirement of the roof structure is high, such as control water and root. Thus the new combined container roof garden is needed. The garden is made up of a new type of cultivation container which can reservoir water and control root, the construction is not only simple, but also without structural damage to the roof. Besides, the containers can be optionally assembled into different types of garden landscape, so it provides a new way to the roof garden construction. This is a new roof greening technology, since the objective of this study was to explore its impact on architecture and micro climate.

\section{Materlals and methods}

\subsection{Study site}

The experimental test was carried out at the roof garden in the second discipline building of Shanghai Institute of Technology located in Fengxian District (Shanghai, China) from September 2013. The building roof had an area of about $290 \mathrm{~m} 2$. The garden was set on a roof under which there was a wall in north. The control (CK) was located in the third discipline building of Shanghai Institute of Technology. The roof garden is divided into three regions represented by A, B and C. For every region, there were different plants (see table 1). 
Table 1. The distribution of plants in the Roof Garden

\begin{tabular}{|c|c|c|c|c|c|}
\hline Region & Area & Green area & Plant species & Plant height & Crown breadth \\
\hline \multirow{10}{*}{ A } & \multirow{10}{*}{$112 \mathrm{~m}^{2}$} & \multirow{10}{*}{$81 \mathrm{~m}^{2}$} & Camellia japonica $L$. & $260 \mathrm{~cm}$ & $82 \mathrm{~cm}$ \\
\hline & & & Camellia sasanqua & $42.5 \mathrm{~cm}$ & $65 \mathrm{~cm}$ \\
\hline & & & $\begin{array}{c}\text { Mordencvs.of Chlimbers and } \\
\text { Ramblers }\end{array}$ & $253 \mathrm{~cm}$ & I \\
\hline & & & Rhododendron simsii Planch. & $38 \mathrm{~cm}$ & $52 \mathrm{~cm}$ \\
\hline & & & Podocarpusmacrophyllus & $130 \mathrm{~cm}$ & $120 \mathrm{~cm}$ \\
\hline & & & Buxusmegistophylla. & $120.0 \mathrm{~cm}$ & $110 \mathrm{~cm}$ \\
\hline & & & Portulaca grandiflora & / & / \\
\hline & & & Photiniaxfraseri & $38.5 \mathrm{~cm}$ & $35 \mathrm{~cm}$ \\
\hline & & & Artificial Grass & l & / \\
\hline & & & Nandinadomestica. & $42.0 \mathrm{~cm}$ & $23 \mathrm{~cm}$ \\
\hline \multirow{6}{*}{ B } & \multirow{6}{*}{$95 \mathrm{~m}^{2}$} & \multirow{6}{*}{$69 \mathrm{~m}^{2}$} & Nymphaea L & / & / \\
\hline & & & Juncuseffusus $L$ & $40 \mathrm{~cm}$ & / \\
\hline & & & Phyllostachysheteroclada & $270 \mathrm{~cm}$ & $26 \mathrm{~cm}$ \\
\hline & & & Camellia japonica $L$. & $260 \mathrm{~cm}$ & $82 \mathrm{~cm}$ \\
\hline & & & Artificial Grass & / & I \\
\hline & & & Tulbaghiaviolacea & $37 \mathrm{~cm}$ & / \\
\hline \multirow{6}{*}{$\mathrm{C}$} & \multirow{6}{*}{$83 \mathrm{~m}^{2}$} & \multirow{6}{*}{$48 \mathrm{~m}^{2}$} & Nandinadomestica & $42 \mathrm{~cm}$ & $23 \mathrm{~cm}$ \\
\hline & & & Brassica campestris L. & / & / \\
\hline & & & Camellia sasanqua & $42.5 \mathrm{~cm}$ & $65 \mathrm{~cm}$ \\
\hline & & & Artificial Grass & I & I \\
\hline & & & $\begin{array}{l}\text { Brassica oleracea var. } \\
\text { acephalaf.tricolor }\end{array}$ & / & / \\
\hline & & & Capsicum frutescensvar.fasciculatum & $36 \mathrm{~cm}$ & $22 \mathrm{~cm}$ \\
\hline
\end{tabular}

\subsection{Methods}

The measurements were carried out in the roof garden A, B, C as well as the east side of the three corresponding office rooms and the control respectively, to select 3 measuring points placed in the temperature and humidity recorder (SIN-TH402), the measured height was $1.5 \mathrm{~m}$. The measurements were made from 26th July 2015 to 28th July 2015, all parameters were measured and recorded at 1 hour intervals from 8 a.m. to 6 p.m. Besides, using infrared temperature measuring instrument (GM320 Benetech) to measure the surface temperature of the wall, each group was measured at 5 points, and take the average value.

\section{Results and discussion}

\subsection{Influence of roof garden on air temperature}

Fig. 1 showed that the air temperature in roof garden was lower than $\mathrm{CK}$ at all time points. The regional air temperature in roof garden was more than $34.3^{\circ} \mathrm{C}$, while the temperature of the no green roof was $35.8^{\circ} \mathrm{C}$, the maximum temperature difference was $1.9^{\circ} \mathrm{C}$. The mean daily temperature of the green roof was $31.9^{\circ} \mathrm{C}$, while the mean temperature of the no green roof was $30.4-31.1^{\circ} \mathrm{C}$, the maximum daily mean temperature was $1.5^{\circ} \mathrm{C}$. In accordance with a study conducted by Wang (2006), we found that no roof greening and roof garden temperature difference from 11 a.m. began to increase[11]. The reason was that the north side of each group had building block, before 11 a.m. solar radiation was weak, and began from 12 a.m. two roofs were subject to the strong influence of solar radiation.

There was no significant difference between the A, B and C regions in roof garden before the 11 a.m., that may be due to the temperature of the exposed roof and the roof garden have the same growth rate before 11 a.m. The temperature difference began to increase after 11 a.m. The region $\mathrm{A}$ (mainly shrub and small arbors) temperature was the lowest, from this comparison, it could be concluded that the roofing materials has a great impact on the heat transfer through the roof [12-15]. 


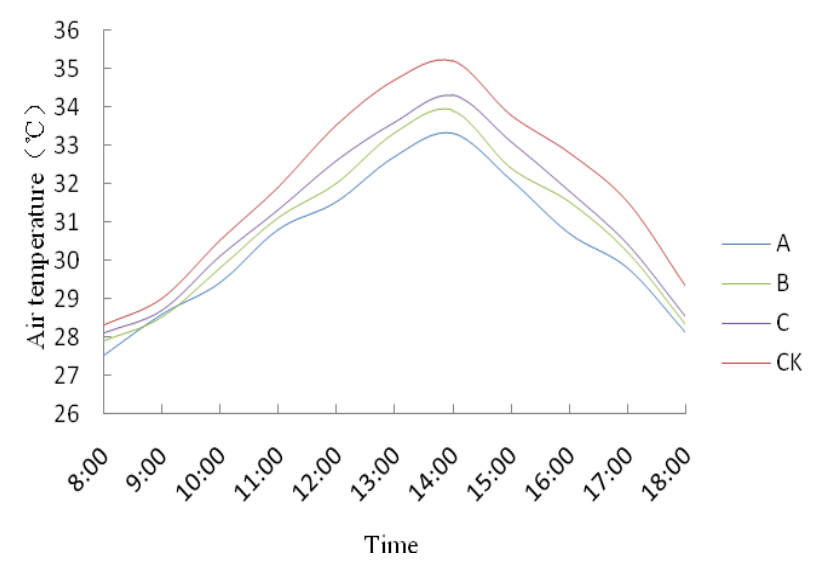

\subsection{Influence of roof garden on air humidity}

Fig. 1 The diurnal variation of air temperature

The air relative humidity in roof garden (69.09\%-72.36\%) was much higher than that in no greening roof $(58.64 \%)$ during the day. The daily minimum air relative humidity difference between roof garden and the control was greatest at 4 p.m. and least 9 a.m., as seen in Fig.2. These results suggest that plants can increase the air relative humidity through the transpiration effectively.

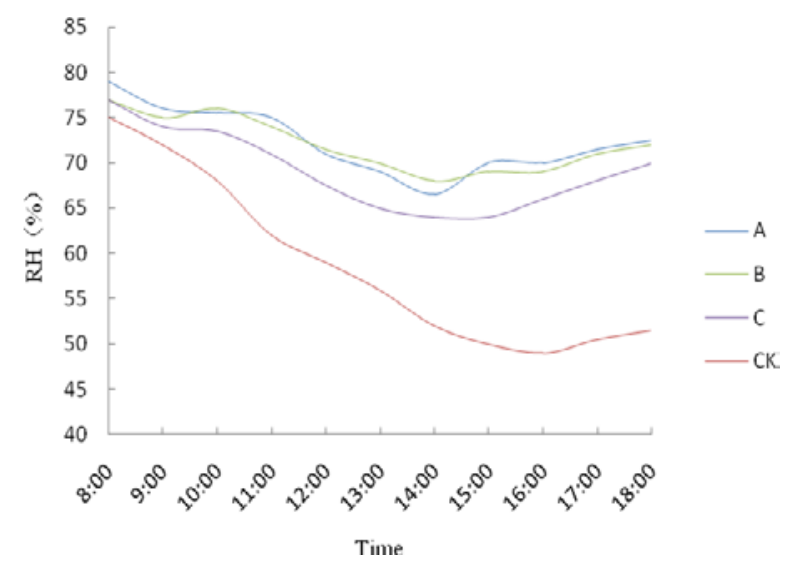

Fig.2 The diurnal variation of air relative humidity

The air relative humidity of region $C$ had significant difference with the A and B began 11 a.m., but there was no significant difference between the A and B. The average daily air relative humidity of A, B and C were $72.36 \%, 72.05 \%$ and $69.09 \%$. Fro this difference, it could be as the different greening area and plant species [16], the region $C$ was not only consistent with herbs and shrubs, but also small. There were shrub and small arbors in region A. Although the green area in region B was smaller than $\mathrm{A}$, but it had aquatic plants and small fountain.

\subsection{The influence of roof garden on the surface temperature of the wall}

There was no significant difference between the temperature of different walls before 11 a.m., this may be the influence of the roof on the east side of the building leading to less solar radiation. After 11 a.m. the temperature of roof gardenwall was significantly lower than that of no roof greening wall, roof garden wall of the daily mean temperature was $34.1^{\circ} \mathrm{C}-38.3^{\circ} \mathrm{C}$, and no greening roof wall of average daily temperature was $41.8^{\circ} \mathrm{C}$, the reason was that plants reduced the influence of solar radiation on the wall, so prevent from the high temperature air[17].We also found that the maximum temperature of the no greening roof wall appeared at 2 p.m., while the maximum temperature of the green roof appeared at 12 p.m., the maximum temperature difference was 14.2, which was also proved by other studies [18].

The roof garden range of temperature began to increase at 11 a.m., which the region $\mathrm{C}$ temperature was highest as Camellia sasanqua were planted in C. Camellia sasanqua was (Camellia) that obstructed smaller area of the wall, leading to the higher wall temperature. And the difference 
between B and C mainly because of the different plants had the different shaded areas on the wall, in addition, the ability of leaves to absorb solar radiation was different $[13,19]$.

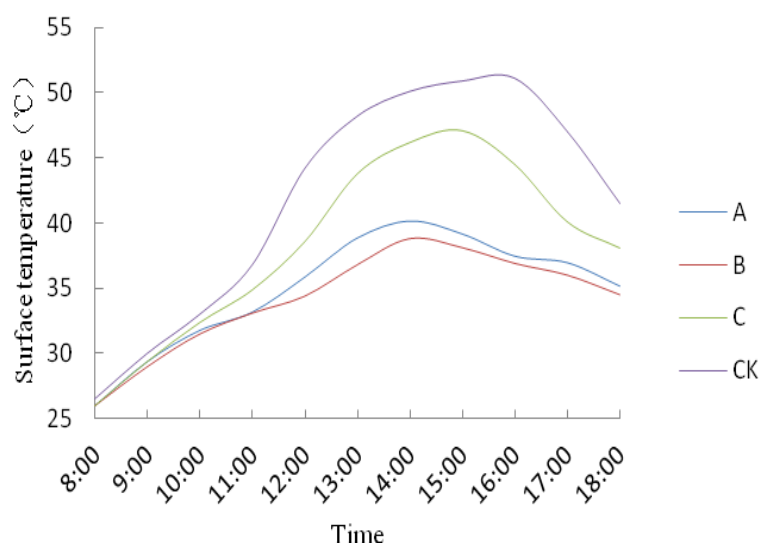

Fig. 3 The diurnal variation of wall surface temperature

\subsection{The influence of roof garden on indoor temperature}

The temperature difference among the groups began to increase at 11a.m., the east room temperature of $\mathrm{C}$ and the control was higher than the $\mathrm{A}$ and $\mathrm{B}$, and the maximum temperature was $42.1^{\circ} \mathrm{C}$ when at $3 \mathrm{p} . \mathrm{m}$. The maximum temperature was $34.3^{\circ} \mathrm{Cappeared}$ at $2 \mathrm{p}$. m. and the maximum temperature difference is $8.9^{\circ} \mathrm{C}$. The daily average temperature of the eastern side room of the control was $34.9{ }^{\circ} \mathrm{C}$, and the A was $30.6{ }^{\circ} \mathrm{C}$ which is lower than that of the east side of the control. The comparison among different regions in rooftop garden revealed that the provision of vegetation on roof could reduce the heat gain into the building.

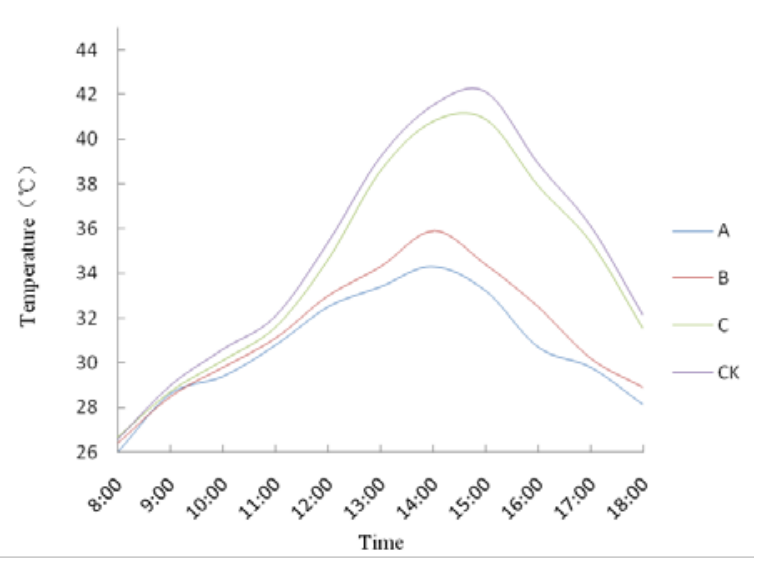

Fig. 4 The diurnal variation of indoor temperature The largest difference of room temperature between $\mathrm{A}$ and $\mathrm{B}$ was $1.6^{\circ} \mathrm{C}$. Therefore, the type of plants, plant leaf density and the ability of absorb solar radiation remained as the reasons for the results $[17,19]$.

\section{Conclusion}

This study has shown that the combined container roof garden can effectively improve the roof microclimate, reduce the highest air temperature $1.9^{\circ} \mathrm{C}$, increase the daily average air relative humidity $13.72 \%$. The study also shows that the combined container roof garden can reduce surface temperature and indoor temperature of buildings, reduce surface temperature $14.2{ }^{\circ} \mathrm{C}$ and reduce indoor temperature $8.9^{\circ} \mathrm{C}$ mostly. The different regions in roof garden has the influence on microclimate and the wall temperature and the indoor temperature, the reason is different regions have diverse green space and plants. It is more obvious to improve the micro climate when green areas are larger, and shrub and small arbors as the most suitable plant for the roof garden. 


\section{References}

[1]. N.H Wong, D.K.W Cheong. The effects of rooftop garden on energy consumption of a commercial building in Singapore,Energy and Buildings.Vol.35(2003)No.4, p.353-364.

[2]. A Niachou. Analysis of the green roof thermal properties and investigation of its energy performance. Energy and Buildings .Vol.33(2001) p.719-29.

[3].T Carter, CR Jackson. Vegetated roofs for stormwater management at multiple spatial scales. Landscape and Urban Planning .Vol.80(2007) p.84-94.

[4].R.R Coffman.Vegetated roof systems: design, productivity, retention, habitat,and sustainability in green roof and ecoroof technology. Doctor's dissertation,Ohio State University, Horticulture and Crop Science. 2007.

[5]. Information on: http://www.winnebagomastergardeners.org

[6].E.G McPherson, J.R Simpson.Potential energy savings in buildings by an urban tree planting programme in California. Urban Forestry and Urban Greening Vol.2(2003) No. 2 , p.73-86.

[7].K.P Beckett, P.H Freer-Smith.Urban woodlands: their role in reducing the effects of particulate pollution. Environmental Pollution .Vol.99(1998) No.3,p.347-360.

[8].H Upmanis, I Eliasson.Case studies of the spatial variation of benzene and toluene concentrations in parks and adjacent built-up areas.WaterAir and Soil Pollution .Vol.129(2001) p.61-81.

[9].A Dimoudi, M Nikolopoulou.Vegetation in the urban environment: microclimatic analysis and benefits. Energy and Buildings Vol.35(2003) No. 1, p.69-76.

[10].C.F Fang, D.L Ling.Guidance for noise reduction provided by tree belts.Landscape and Urban Planning Vol.71(2005) No. 1, p.29-34.

[11].Z Wang.A field study of the thermal comfort in residential buildings in Harbin. Building and Environment Vol.41(2006) p.1034-1039.

[12].L Wang, J Qin.Influence of Roof Garden on Architecture Microclimates.Chinese Agricultural Science Bulletin. Vol.22(2006) No. 2, p. 236-238.

[13].T.S Nielsen, K.B Hansen.Do green areas affect health? Results from a Danishsurvey on the use of green areas and health indicators. Health \& Place Vol.13(2007) No. 4, p.839-850.

[14].N.H Wong, Y Chen. Study of thermal performance of extensive rooftop greenery systems in the tropical climate,Building and Environment.Vol. 42(2007), p.25-54.

[15]. Information on: http://www.ecoroofsystems.com/cost.html.

[16].R.A Sproken-Smith, T Oke.The thermal regime of urban parks in two cities with different summer climates. International Journal of Remote Sensing. Vol.19(1998 ) No.11, p.2085-2104 .

[17].H Upmanis, D Chen.Influence of geographical factors and meteorologicalvariables on nocturnal urban-park temperature differences-a case study of summer 1995 in Göteborg, Sweden. Climate Research. Vol. 13(1999), p.125-139.

[18].L.T Chun, Y.T Puay.Impact of plant evapotranspiration rate and shrub albedo on temperature reduction in the tropical outdoor environment. Building and Environment. Vol. 94(2015) p.206-217.

[19].A. M Hunter, N. S. G Williams. Quantifying the thermal performance of green façades: A critical review. Ecological Engineering. Vol. 63(2014) , p.102-113. 